\title{
PENGARUH LINGKUNGAN WAJIB PAJAK, KONTROL KEPERILAKUAN YANG DIPERSEPSIKAN DAN KEWAJIBAN MORAL TERHADAP KEPATUHAN WAJIB PAJAK ORANG PRIBADI DI KELURAHAN PAAL DUA MANADO
}

\author{
Pricillia V.E Kawengian $^{1}$, Harijanto Sabijono ${ }^{2}$, Novi S. Budiarso ${ }^{3}$ \\ ${ }^{1,2,3}$ Fakultas Ekonomi dan Bisnis . Jurusan Akuntansi. Universitas Sam Ratulangi, Jl. Kampus Bahu, Manado, \\ 95115, Indonesia
}

E-mail :priciliakawengian77@gmail.com

\begin{abstract}
Taxpayer Compliance is an obedient attitude of the taxpayer in carrying out the provisions and tax regulations that are required and should be implemented. Taxpayer compliance may be influenced by the taxpayer's environment, perceived behavioral control and moral obligations. The population in this research is Individual Taxpayer in Kelurahan Paal Dua Manado. The sample in this research is 50 respondents with sampling technique using incidental sampling technique. Methods of collecting data with questionnaires. This study used multiple linear regression method with the help of SPSS. The results show that the taxpayer Environment ( ) and Moral Obligations ( ) have an influence on taxpayer compliance $(Y)$. Perceived Behavioral Control ( ） has no effect on taxpayer compliance $(Y)$. Keywords: taxpayer environment, Perceived Behavioral Control, Moral Obligations and taxpayer compliance.
\end{abstract}

\section{PENDAHULUAN}

\subsection{Latar Belakang}

Pajak dapat diartikan sebagai pungutan yang dilakukan oleh Negara terhadap warga negaranya, berdasarkan undang-undang yang berlaku dimana atas pungutan tersebut Negara tidak memberikan kontraprestasi secara langsung kepada pembayar pajak (Jotopurnomo dan Mangoting, 2013).

Pada umumnya pendapatan Negara merupakan sumber utama belanja Negara disamping komponen pembiayaan APBN yang meliputi penerimaan pajak dan bukan pajak. Dalam upaya mengurangi ketergantungan sumber eksternal, pemerintah Indonesia secara terus menerus berusaha meningkatkan sumber pembiayaan pembangunan internal, salah satu sumber pembiayaan pembangunan internal tersebut adalah pajak (Yuliyanti, 2016).

Pajak yang terutang yang lalai dilunasi oleh wajib pajak akan terakumulasi menjadi tunggakan pajak yang berpotensi mengurangi penerimaan pajak. Oleh karena itu, kepatuhan wajib pajak dalam memenuhi kewajiban perpajakanya sangatlah dibutuhkan (Artha dan Setiawan, 2016).

Saat ini peningkatan dari sektor pajak sebagai salah satu sumber penerimaan Negara yang masih sangat dimungkinkan dan memiliki peluang yang sangat luas. Hal ini dapat dilihat dari jumlah wajib pajak baik wajib pajak orang pribadi maupun wajib pajak badan yang setiap tahunya semakin bertambah seiring bertambahnya jumlah penduduk dan kesejahteraan masyarakat (Aryobimo, 2012).

Untuk itu pemerintah berusaha keras dalam meningkatkan penerimaan Negara. Namun, usaha dalam meningkatkan penerimaan Negara disektor pajak masih mempunyai banyak kendala yaitu antara lain tingkat kepatuhan wajib pajak yang masih rendah, sehingga wajib pajak berusaha untuk membayar kewajiban pajaknya yang lebih kecil dari yang seharusnya dan juga masih banyak wajib pajak yang tidak melaporkan dan membayarkan pajaknya. 
Kepatuhan wajib pajak dapat dipengaruhi oleh beberapa faktor diantaranya lingkungan dari wajib pajak berada, kontrol keperilakuan yang dipersepsikan, dan kewajiban moral yang dapat memberikan pengaruh terhadap tingkat kepatuhan wajib pajak.

\subsection{Rumusan Masalah}

1. Apakah lingkungan wajib pajak berpengaruh terhadap kepatuhan wajib pajak orang pribadi di Kelurahan Paal Dua Manado?

2. Apakah kontrol keperilakuan yang dipersepsikan berpengaruh terhadap kepatuhan wajib pajak orang pribadi di Kelurahan Paal Dua Manado?

3. Apakah kewajiban moral berpengaruh terhadap kepatuhan wajib pajak orang pribadi di Kelurahan Paal Dua Manado?

\subsection{Tujuan Penelitian}

Berdasarkan rumusan masalah yang ada, maka tujuan dalam penelitian ini adalah se bagai berikut.

1. Untuk mengetahui pengaruh lingkungan wajib pajak terhadap kepatuhan wajib pajak orang pribadi di Kelurahan Paal Dua Manado.

2. Untuk mengetahui pengaruh kontrol keperilakuan yang dipersepsikan terhadap kepatuhan wajib pajak orang pribadi di Kelurahan Paal Dua Manado.

3. Untuk mengetahui pengaruh kewajiban moral terhadap kepatuhan wajib pajak orang pribadi di Kelurahan Paal Dua Manado.

\section{TINJAUAN PUSTAKA}

\subsection{Landasan Teori}

\subsubsection{Akuntansi}

Menurut Warren, et al (2014:3), akuntansi diartikan sebagai sistem informasi yang menyediakan laporan untuk para pemangku kepentingan mengenai aktifitas ekonomi dan kondisi perusahaan.

\subsubsection{Akuntansi Pajak}

Menurut Pohan (2013:10), akuntansi perpajakan merupakan salah satu dimensi akuntansi yang menyediakan informasi yang berhubungan dengan aspek perpajakan, tentang bisnis dan transaksi keuangan kepada mereka yang ingin mengelola bisnis dan transaksi keuangan dan aspek perpajakan dari suatu entitas akuntansi.

\subsubsection{Pengertian Pajak}

Menurut Waluyo (2013:2), yaitu pajak adalah iuran kepada Negara (yang dapat dipaksakan) yang terutang oleh yang wajib membayarnya menurut peraturan-peraturan, dengan tidak mendapat prestasi kembali yang langsung dapat ditunjuk dan yang gunanya adalah untuk membiayai pengeluaran-pengeluaran umum berhubung dengan tugas Negara yang menyelenggarakan pemerintahan.

\subsubsection{Pengertian Kepatuhan Wajib Pajak}

Menurut Primasari (2016), kepatuhan wajib pajak merupakan perilaku/tingkah laku wajib pajak untuk melaksanakan hak perpajakanya dan memenuhi kewajiban perpajakanya seperti membuat NPWP, mengisi secara benar jumlah pajak yang terutang, membayar pajak tepat pada waktunya tanpa ada pemaksaan, serta memasukkan dan melaporkan pada waktunya informasi yang diperlukan sesuai dengan peraturan perpajakan yang berlaku.

\subsubsection{Lingkungan Wajib Pajak}

Menurut Jotopurnomo dan Mangoting (2013), lingkungan adalah sesuatu yang ada di alam sekitar yang memiliki makna atau pengaruh tertentu kepada individu. Lingkungan dapat mempengaruhi sesorang untuk compliance dan non compliance tidak dapat ditinjau dari satu variabel penyebab saja. 


\subsubsection{Kontrol Keperilakuan yang dipersepsikan}

Dalam model Theory of Planned Behavior (TPB), kontrol perilaku yang dipersepsikan mengacu kepada persepsi seseorang terhadap sulit tidaknya melaksanakan perilaku yang diinginkan, terkait dengan keyakinan akan tersedia atau tidaknya sumber dan kesempatan yang diperlukan untuk mewujudkan perilaku tertentu (Hidayat dan Nugroho, 2010). Menurut Winarsih (2015), kontrol perilaku yang dipersepsikan adalah sejumlah kontrol yang diyakini wajib pajak yang akan menghambat mereka dalam menampilkan perilaku ketidakpatuhan pajak.

\subsection{Kerangka Pemikiran}

Gambar 2.1 Kerangka Pemikiran

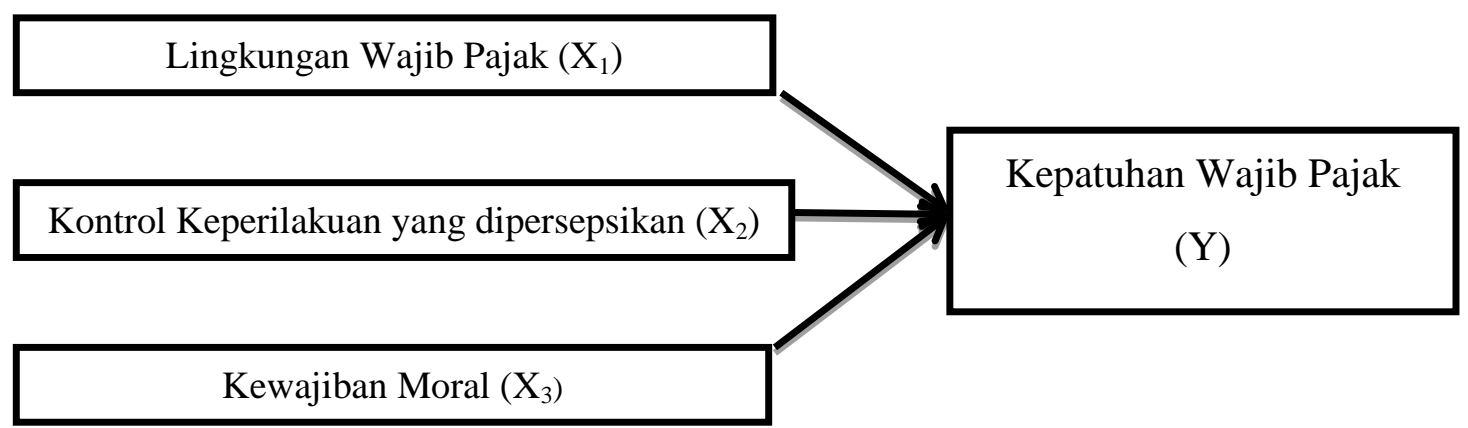

Sumber: Data Diolah (2017)

\subsection{Hipotesis}

:Lingkungan wajib pajak berpengaruh terhadap kepatuhan wajib pajak orang pribadi di Kelurahan Paal Dua Manado.

:Kontrol keperilakuan yang dipersepsikan berpengaruh terhadap kepatuhan wajib pajak orang pribadi di Kelurahan Paal Dua Manado.

$\mathrm{H}_{3}$ :Kewajiban Moral berpengaruh terhadap kepatuhan wajib pajak orang pribadi di Kelurahan Paal Dua Manado.

\subsection{Penelitian Terdahulu}

1. Ella Widyastuti (2015), dengan judul Pengaruh tingkat pemahaman wajib pajak, kualitas pelayanan fiskus, sanksi perpajakan, dan lingkungan wajib pajak terhadap tingkat kepatuhan wajib pajak orang pribadi (Studi empiris pada KPP Pratama Surakarta). Dengan menggunakan metode analisis regresi berganda. Hasil penelitian menunjukkan tingkat pemahaman tentang pajak, kualitas pelayanan fiskus, sansksi perpajakan, dan lingkungan wajib pajak berpengaruh positif terhadap kepatuhan wajib pajak orang pribadi. Peneliti sebelumnya melakukan penelitian dengan variabel yang sama yaitu variabel lingkungan wajib pajak dan variabel kepatuhan wajib pajak. Perbedaan yang ditemukan dengan penelitian sebelumnya terdapat pada objek penelitian.

2. Endang Sri Winarsih (2015), dengan judul Faktor-Faktor yang mempengaruhi niat ketidakpatuhan dalam membayar pajak. Dengan menggunakan metode analisis regresi linier berganda. Hasil penelitian menunjukkan sikap, norma subyektif, kewajiban moral, dan kontrol perilaku yang dipersepsikan berpengaruh positif terhadap niat ketidakpatuhan dalam membayar pajak. Peneliti sebelumnya melakukan penelitian dengan variabel yang sama yaitu variabel kewajiban moral dan kontrol perilaku yang dipersepsikan. Perbedaan yang ditemukan dengan penelitian seblumnya terdapat pada objek penelitian. 


\section{METODE PENELITIAN}

\subsection{Jenis Penelitian}

Penelitian ini menggunakan jenis penelitian deskriptif kuantitatif dengan menggunakan analisis regresi linier berganda.

\subsection{Tempat dan Waktu Penelitian}

Penelitian ini mengambil data di seluruh lingkungan di Kelurahan Paal Dua Manado yang berlangsung dari bulan Juli-Agustus 2017.

\subsection{Populasi dan Sampel Penelitian}

Populasi diartikan sebagai wilayah generalisasi yang terdiri atas: obyek/subjek yang mempunyai kualitas dan karakteristik tertentu yang ditetapkan oleh peneliti untuk dipelajari dan kemudian ditarik kesimpulannya (Sugiyono, 2016:80). Populasi penelitian ini adalah seluruh WP orang pribadi yang terdaftar di Kelurahan Paal Dua Manado.

Sampel adalah bagian dari jumlah dan karakteristik yang dimiliki oleh populasi tersebut (Sugiyono, 2016:81). Penentuan sampel menggunakan sampling insidental. Sampling insidental adalah teknik penentuan sampel berdasarkan kebetulan, yaitu siapa saja yang secara kebetulan/incidental bertemu dengan peneliti dapat digunakan sebagai sampel, bila dipandang orang yang kebetulan ditemui itu cocok sebagai sumber data (Sugiyono, 2016:85). Jadi, sampel dalam penelitian ini adalah 50 responden dengan penyebaran 5 responden setiap kelurahan.

\subsection{Metode Pengumpulan Data}

\subsubsection{Jenis Data}

Jenis data yang digunakan dalam penelitian ini adalah data kuantitatif yang berupa nilai atau skor atas jawaban yang diberikan oleh responden terhadap pertanyaan-pertanyaan yang terdapat dalam kuesioner.

\subsubsection{Sumber Data}

Data primer yang dihasilkan dalam penelitian ini adalah merupakan hasil dari tanggapan responden terhadap variabel-variabel penelitian yang akan diuji.

\subsection{Metode Analisis Data}

Metode analisis data yang digunakan dalam penelitian ini adalah analisis regresi linier berganda (Multiple Regression Analysis) dengan bantuan program Statistical Product and Service Solution (SPSS). Analisis ini dimaksudkan untuk mengungkapkan pengaruh antara beberapa variabel bebas dengan variabel terikat.

\subsubsection{Statistik Deskriptif}

Statistik deskriptif adalah statistik yang digunakan untuk menganalisis data cara mendeskripsikan atau menggambarkan data yang telah terkumpul sebagaimana adanya tanpa bermaksud membuat kesimpulan yang berlaku umum atau generalisasi (I'anatut Thoifah, 2015:75).

\subsubsection{Uji Kualitas Data}

\subsubsection{Uji Validitas}

Sebuah kuesioner yang digunakan dalam penelitian harus valid. Arti valid disini yaitu mampu menunjukkan sampai sejauh mana alat ukur mampu mengukur apa yang ingin diukur. Pada uji validitas ini, digunakan korelasi product moment pearson (metode interkorelasi). Cara pengukurannya yaitu menghitung korelasi antara skor masing-masing item pertanyaan pada kuesioner skor total kuesioner. Jika nilai $r_{\text {hitung }}>r_{\text {tabel }}$ dan atau nilai sig $<0,05$ maka item pertanyaan tersebut dianggap valid (I'anatut Thoifah, 2015:111). 


\subsubsection{Uji Reliabilitas}

Selain sebuah kuesioner harus valid, kuesioner juga harus reliabel. Arti dari reliabel di sini adalah mempunyai presisi yang tinggi. Yaitu dimana suatu alat ukur mampu menunjukkan sampai sejauh mana alat ukur tersebut dapat dipercaya atau diandalkan. Cara pengukurannya adalah seluruh item pertanyaan yang telah valid dimasukkan dan diukur koefisien Alpha Cronbachnya. Jika nilai yang diperoleh lebih besar dari 0,6 maka kuesioner tersebut telah reliabel (I'anatut Thoifah, 2015:114).

\subsubsection{Asumsi Klasik}

\subsubsection{Uji Normalitas}

Uji normalitas bertujuan untuk membuktikan bahwa data yang dipergunakan berdistribusi normal. Pengujian asumsi normalitas ini untuk menguji data variabel bebas (X) dan variabel terikat $(\mathrm{Y})$ pada persamaan regresi yang dihasilkan, apakah berdistribusi normal atau berdistribusi tidak normal. Dasar pengambilan keputusan dalam uji normalitas yakni : jika probabilitas lebih besar dari 0,05 maka data tersebut berdistribusi normal. Sebaliknya jika probabilitas kurang dari 0,05 maka data tersebut tidak berdistribusi normal (I'anatut Thoifah, 2015:221).

\subsubsection{Uji Multikoliniearitas}

Uji multikolinieritas bertujuan untuk menguji apakah dalam model regresi ditemukan adanya korelasi antara variabel independen. Menurut Ghozali (2013: 91), uji ini bertujuan untuk menguji apakah dalam model regresi ditemukan adanya korelasi antar variabel-variabel bebas. Pada model regresi yang baik seharusnya tidak terjadi korelasi di antara variabel bebas/variabel independen. Jika variabel bebas saling berkorelasi, maka variabel ini tidak orthogonal. Variabel orthogonal adalah variabel bebas yang nilai korelasi antara variabel bebasnya sama dengan nol. Dasar pengambilan keputusan, jika nilai tolerance $<0,10$ atau VIF $>10$ maka terjadi multikoliniearitas sedangkan jika nilai tolerance $>0,10$ atau VIF $<10$ maka tidak terjadi multikoliniearitas.

\subsubsection{Uji Autokorelasi}

Uji autokorelasi dimaksudkan untuk mengetahui apakah terjadi korelasi antara residual (anggota) pada serangkaian observasi tertentu dalam suatu periode tertentu. Dalam penelitian ini digunakan metode uji Durbin Watson. Menurut Durbin Watson, besarnya koefisien adalah antara 0-4. Kalau koefisien Durbin Watson sekitar 2, maka dapat dikatakan tidak ada korelasi, kalau besarnya mendekati 0, maka terdapat autokorelasi positif dan jika besarnya mendekati 4, maka terdapat autokorelasi negatif (I'anatut Thoifah, 2015:222).

\subsubsection{Uji Heteroskedastisitas}

Heteroskedastisitas merupakan ketidaksamaan variasi variabel pada semua pengamatan dan kesalahan yang terjadi dalam memperlihatkan hubungan yang sistematis sesuai dengan besarnya satu/lebih variabel independen sehingga kesalahan tersebut tidak random (I'anatut Thoifah, 2015:222).

\subsubsection{Uji Hipotesis}

\subsubsection{Uji Pengaruh Simultan ( Uji f)}

Menurut Sugiyono (2014:192), uji f digunakan untuk mengetahui apakah secara simultan koefisien variabel bebas mempunyai pengaruh nyata atau tidak terhadap variabel terikat.

Untuk menguji apakah masing-masing variabel bebas berpengaruh secara signifikan terhadap variabel terikat secara bersama-sama dengan $\alpha=0,05$. Maka cara yang dilakukan adalah:

a. Bila signifikansi $<0,05$ artinya variabel independen secara simultan mempengaruhi variabel dependen.

b. Bila signifikansi $>0,05$ artinya variabel independen secara simultan tidak mempengaruhi variabel dependen. 


\subsubsection{Uji Pengaruh Parsial (Uji t)}

Menurut Sugiyono (2014: 194), uji t digunakan untuk mengetahui masing-masing sumbangan variabel bebas secara parsial terhadap variabel terikat, menggunakan uji masingmasing koefisien regresi variabel bebas apakah mempunyai pengaruh yang bermakna atau tidak terhadap variabel terikat.

Untuk menguji apakah masing-masing variabel bebas berpengaruh secara signifikan terhadap variabel terikat secara parsial dengan $\alpha=0,05$. Maka cara yang dilakukan adalah:

a) Bila signifikansi $<0,05$ artinya variabel independen secara parsial mempengaruhi variabel dependen.

b) Bila signifikansi $>0,05$ artinya variabel independen secara parsial tidak mempengaruhi variabel dependen.

Untuk mencari $\mathrm{t}$ tabel dihitung dengan $\mathrm{df}=\mathrm{n}-\mathrm{k}-1$, di mana $\mathrm{n}$ adalah jumlah responden dan k adalah jumlah variabel. Significance level 5\% dapat dilihat dengan menggunakan tabel statistik. Nilai tabel dapat dilihat dengan menggunakan tabel $\mathrm{t}$.

\subsubsection{Koefisien Determinasi $\left(\mathbf{R}^{2}\right)$}

Menurut Ghozali (2013:97), koefisien determinasi $\left(R^{2}\right)$ pada intinya mengukur seberapa jauh kemampuan model dalam menerangkan variasi variabel dependen. Uji koefisien determinasi $\left(R^{2}\right)$ dilakukan untuk mengetahui seberapa besar persentase sumbangan dari variabel independen secara bersama-sama terhadap variabel dependen. Uji ini dilihat dari seberapa besar variabel independen yang digunakan dalam penelitian mampu menjelaskan variabel dependen.

\subsection{Definisi dan Pengukuran Variabel \\ 3.6.1 Variabel Dependen \\ 3.6.1.1 Kepatuhan Wajib Pajak}

Kepatuhan wajib pajak merupakan suatu sikap patuh dalam memenuhi kewajibanya sebagai wajib pajak. Variabel ini diukur dengan menggunakan indikator yang dikembangkan oleh Alfiah (2014), yaitu wajib pajak paham terhadap pendaftaran NPWP, pemahaman terhadap prosedur pengisian SPT menurut Undang-Undang yang berlaku, pemahaman terhadap pelaporan SPT dan perhitungan pajak penghasilan, pemahaman terhadap kepatuhan membayar pajak dan sanksi administrasi. Diukur dengan instrument yang terdiri dari 6 pertanyaan. Skala pengukuran yang digunakan adalah skala likert lima poin yaitu $1=$ sangat tidak setuju, $2=$ tidak setuju, $3=$ ragu, $4=$ setuju, dan $5=$ sangat setuju.

\subsubsection{Variabel Independen}

\subsubsection{Lingkungan Wajib Pajak}

Lingkungan merupakan sesuatu yang ada disekitar wajib pajak yang memiliki makna atau pengaruh tertentu kepada wajib pajak yang dapat memberikan dorongan bagi wajib pajak dalam melaksanakan kewajiban perpajakan dengan benar atau tidak. Variabel ini diukur menggunakan indikator yang dikembangkan oleh Widyastuti (2015), dengan beberapa modifikasi. Indikator lingkungan wajib pajak yang digunakan ialah masyarakat yang didalamnya mendukung dan mendorong melaporkan serta berperilaku patuh terhadap pajak, masyarakatnya melaporkan pajak secara benar, wajib pajak pajak melaporkan pajak secara benar karena anjuran masyarakat, dan sosisalisasi pajak. Lingkungan wajib pajak diukur dengan instrument yang terdiri dari 5 pertanyaan. Pengukuran yang digunakan adalah skala likert lima poin yaitu $1=$ sangat tidak setuju, $2=$ tidak setuju, $3=$ ragu, $4=$ setuju, dan $5=$ sangat setuju.

\subsubsection{Kontrol Keperilakuan yang dipersepsikan}

Kontrol keperilakuan memiliki arti sejumlah kontrol yang diyakini oleh wajib pajak dapat menghambat mereka melakukan suatu tindakan ketidakpatuhan pajak. Variabel ini diukur dengan menggunakan indikator yang dikembangkan oleh Winarsih (2015), dengan 
beberapa modifikasi. Dengan indikator kontrol keperilakuan yang dipersepsikan adalah adanya sanksi, pelaporan pihak ketiga, dan pemeriksan dari petugas pajak. Kontrol keperilakuan yang dipersepsikan diukur dengan instrument yang terdiri dari 4 pertanyaan. Skala pengukuran yang digunakan adalah skala likert lima poin yaitu $1=$ sangat tidak setuju, $2=$ tidak setuju, $3=$ ragu, $4=$ setuju, dan $5=$ sangat setuju .

\subsubsection{Kewajiban Moral}

Kewajiban moral tidak dipaksakan dari luar tapi diperintahkan dari dalam diri oleh hati nurani dan moral individu wajib pajak. Kewajiban moral merupakan norma individu yang dimiliki seseorang namun kemungkinan tidak dimiliki oleh orang lain. Wajib pajak diharapkan menyadari pentingnya pajak sebagai sumber pembiayaan Negara, sehingga wajib pajak dapat meningkatkan kewajiban moral yang dimiliki oleh wajib pajak itu sendiri agar dapat memenuhi kewajiban dalam membayar pajak. Variabel ini diukur dengan menggunakan indikator yang dikembangkan oleh Rahayu (2015), dengan beberapa modifikasi. Indikator yang dipakai ialah etika, perasaan bersalah, prinsip hidup, dan prosedur sebagai wajib pajak. Diukur dengan instrument yang terdiri dari 4 pertanyaan. Skala pengukuran yang digunakan adalah skala likert lima poin yaitu $1=$ sangat tidak setuju, $2=$ tidak setuju, 3= ragu, 4= setuju, dan 5= sangat setuju.

\section{HASIL PENELITIAN DAN PEMBAHASAN \\ 4.1 Hasil Penelitian \\ 4.1.1 Analisis Data \\ 4.1.1.1 Uji Validitas}

Berikut ini adalah beberapa tabel hasil dari pengujian validitas butir instrumen lingkungan wajib pajak, kontrol keperilakuan yang dipersepsikan, kewajiban moral dan kepatuhan wajib pajak. SPSS versi 21.0 :

\section{Tabel 4.1 Hasil Uji Validitas}

\begin{tabular}{|r|l|c|c|c|}
\hline No. & \multicolumn{1}{|c|}{ Uraian } & Sig & $\mathbf{5 \%}$ & Keterangan \\
\hline 1 & Lingkungan Wajib Pajak ( ) & 0.000 & 0.05 & Valid \\
& Pertanyaan 1 & 0.000 & 0.05 & Valid \\
& Pertanyaan 2 & 0.001 & 0.05 & Valid \\
& Pertanyaan 3 & 0.000 & 0.05 & Valid \\
& Pertanyaan 4 & 0.000 & 0.05 & Valid \\
\hline 2 & Pertanyaan 5 & & & \\
& Kontrol Kperilakuan yang dipersepsikan ( ) & 0.000 & 0.05 & Valid \\
& Pertanyaan 1 & 0.000 & 0.05 & Valid \\
& Pertanyaan 2 & 0.000 & 0.05 & Valid \\
& Pertanyaan 3 & 0.000 & 0.05 & Valid \\
\hline \multirow{2}{*}{3} & Pertanyaan 4 & Kewajiban Moral ( ) & & \\
& Pertanyaan 1 & 0.000 & 0.05 & Valid \\
& Pertanyaan 2 & 0.000 & 0.05 & Valid \\
& Pertanyaan 3 & 0.000 & 0.05 & Valid \\
& Pertanyaan 4 & 0.000 & 0.05 & Valid \\
\hline 4 & Kepatuhan Wajib Pajak (Y) & & & \\
& Pertanyaan 1 & 0.001 & 0.05 & Valid \\
& Pertanyaan 2 & 0.000 & 0.05 & Valid \\
& Pertanyaan 3 & 0.000 & 0.05 & Valid \\
& Pertanyaan 4 & 0.000 & 0.05 & Valid \\
& Pertanyaan 5 & 0.000 & 0.05 & Valid \\
& Pertanyaan 6 & 0.001 & 0.05 & Valid \\
\hline
\end{tabular}

Sumber: Pengolahan Data, 2017

Dari hasil analisis validitas data yang ada, menunjukkan seluruh pernyataan dalam kuesioner untuk setiap variabel dalam penelitian ini telah dinyatakan valid atau sah. Hal ini dapat dilihat dari diperolehnya sig $<0.05$ pada masing-masing variabel dalam penelitian ini. 


\subsubsection{Uji Reliabilitas}

Berikut adalah hasil perhitungan reliabilitas.

Tabel 4.2 Hasil Uji Reliabilitas

\begin{tabular}{|c|c|c|}
\hline Variabel & Cronbach Alpha & Keterangan \\
\hline Lingkungan Wajib Pajak & 0.711 & Reliabel \\
\hline Kontrol Keperilakuan yang dipersepsikan & 0.707 & Reliabel \\
\hline Kewajiban Moral & 0.702 & Reliabel \\
\hline Kepatuhan Wajib Pajak & 0.707 & Reliabel \\
\hline
\end{tabular}

Sumber: Pengolahan Data, 2017

Berdasarkan hasil pengujian reliabilitas yang telah dilakukan yang tertuang pada tabel 4.2 terlihat dari keseluruhan item pernyataan pada setiap variabel memiliki nilai koefisien cronbachs alpha di atas 0.6 maka dapat disimpulkan bahwa seluruh item pernyataan dalam kuesioner untuk setiap variabel sudah handal.

\subsubsection{Hasil Uji Asumsi Klasik}

\subsubsection{Uji Normalitas}

Hasil dari pengolahan data uji multikolinearitas program SPSS versi 21.0 dapat dilihat pada Tabel 4.3.

Tabel 4.3 Hasil Uji Normalitas

One-Sample Kolmogorov-Smirnov Test

\begin{tabular}{|cc|r|}
\hline & & Unstandardized Residual \\
\hline $\mathrm{N}$ & & 50 \\
& & .0000000 \\
Normal Parameters ${ }^{\mathrm{a}, \mathrm{b}}$ & Mean & 1.87536998 \\
& Std. Deviation & .095 \\
& Absolute & .095 \\
Most Extreme Differences & Positive & -.092 \\
& Negative & .674 \\
Kolmogorov-Smirnov Z & & .754 \\
Asymp. Sig. (2-tailed) & & \\
\hline
\end{tabular}

a. Test distribution is Normal.

b. Calculated from data.

Sumber: Pengolahan Data, 2017

Dari data yang ada pada Tabel 4.3, menunjukkan pada Kolmogrov-smirnov dapat diketahui bahwa nilai signifikan untuk seluruh variabel lebih besar dari 0.05 yaitu 0.754 maka dapat disimpulkan bahwa data berdistribusi normal.

\subsubsection{Uji Multikolinieritas}

Hasil dari pengolahan uji Multikolinieritas program SPSS versi 21.0 dapat dilihat pada Tabel 4.4. 


\section{Tabel 4.4 Hasil Uji Multikolinieritas}

Coefficients $^{\text {a }}$

\begin{tabular}{|c|c|c|c|c|c|c|c|}
\hline \multirow[t]{2}{*}{ Model } & \multicolumn{2}{|c|}{$\begin{array}{l}\text { Unstandardized } \\
\text { Coefficients }\end{array}$} & \multirow{2}{*}{ 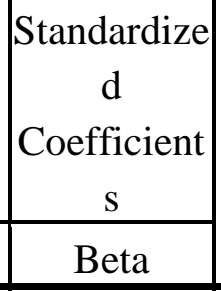 } & \multirow[t]{2}{*}{$\mathrm{t}$} & \multirow[t]{2}{*}{ Sig. } & \multicolumn{2}{|c|}{ Collinearity Statistics } \\
\hline & B & Std. Error & & & & Tolerance & VIF \\
\hline $\begin{array}{c}\text { (Constant } \\
\text { ) }\end{array}$ & 9.227 & 1.940 & & 4.755 & .000 & & \\
\hline $\mathrm{x} 1$ & .360 & .155 & .369 & 2.324 & .025 & .435 & 2.298 \\
\hline $\mathrm{x} 2$ & -.100 & .162 & -.096 & -.616 & .541 & .450 & 2.221 \\
\hline $\mathrm{x} 3$ & .494 & .163 & .469 & 3.022 & .004 & .456 & 2.193 \\
\hline
\end{tabular}

Sumber: Pengolahan Data, 2017

Berdasarkan tabel diatas dapat dilihat bahwa nilai tolerance dari variabel independen lebih dari 0.10 dan VIF kurang dari 10. Hal ini menunjukkan bahwa tidak terjadi multikolinieritas.

\subsubsection{Uji Autokorelasi}

Hasil dari pengolahan data uji autokorelasi menggunakan program SPSS versi 21.0 dapat dilihat pada Tabel 4.5

Tabel 4.5 Hasil Uji Autokorelasi Model Summary ${ }^{\mathrm{b}}$

\begin{tabular}{|r|r|r|r|l|}
\hline $\mathrm{R}$ & $\begin{array}{c}\mathrm{R} \\
\text { Square }\end{array}$ & $\begin{array}{c}\text { Adjusted R } \\
\text { Square }\end{array}$ & $\begin{array}{c}\text { Std. Error of } \\
\text { the Estimate }\end{array}$ & \multicolumn{1}{c|}{ Durbin-Watson } \\
\hline $.703^{\mathrm{a}}$ & .494 & .461 & 1.936 & 1.700 \\
\hline
\end{tabular}

a. Predictors: (Constant), x3, x2, x1

b. Dependent Variable: y

Sumber: Pengolahan Data, 2017

Nilai dU yang didapat dari tabel Durbin Watson adalah 1.673 dan nilai dU $<$ DW < (4-dU) adalah $1.673<1.700<2.327$. Maka dapat disimpulkan bahwa, tidak terjadi autokorelasi baik positif maupun negatif pada penelitian ini.

\subsubsection{Uji Heteroskedastisitas}

Hasil dari pengolahan data uji heteroskedastisitas menggunakan program SPSS versi 21.0 dapat dilihat pada Gambar 4.1 


\section{Gambar 4.1 Hasil Uji Heteroskedastisitas}

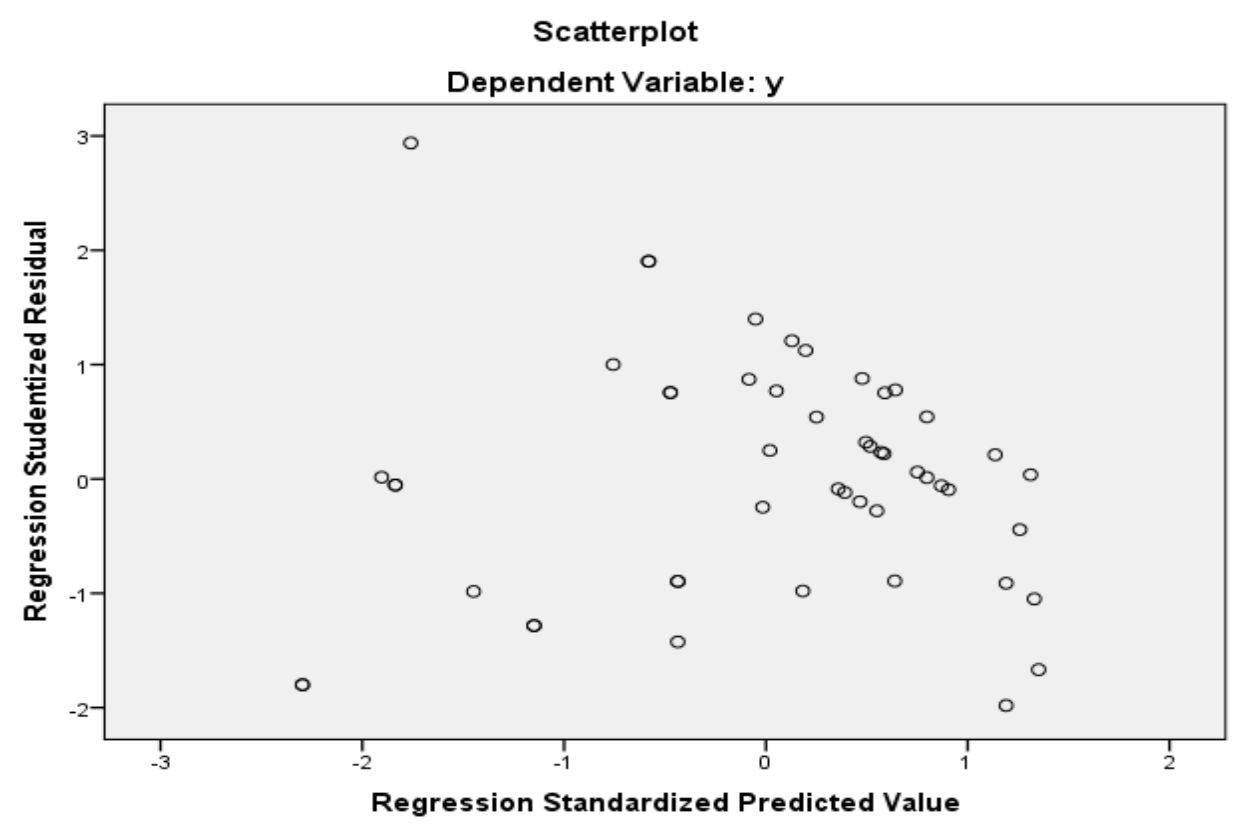

Sumber: Pengolahan Data, 2017

Berdasarkan gambar diatas diketahui bahwa tidak terjadi gejala atau masalah heteroskedastisitas pada model regresi karena titik-titik data menyebar diatas dan dibawah atau disekitar angka 0, titik-titik tidak mengumpul hanya diatas atau dibawah saja, penyebaran titik-titik data tidak membentuk pola bergelombang melebar kemudian menyempit dan melebar kembali, dan penyebaran titik-titik data tidak berpola sehingga, dapat disimpulkan bahwa tidak terjadi masalah heteroskedastisitas pada model regresi.

\subsubsection{Hasil Uji Hipotesis}

\subsubsection{Hasil Uji Simultan (Uji f)}

Tabel 4.6 Hasil Uji Simultan (Uji f)

ANOVA $^{\mathrm{a}}$

\begin{tabular}{|r|r|r|r|c|c|}
\hline \multicolumn{1}{|c|}{ Model } & \multicolumn{1}{c|}{$\begin{array}{c}\text { Sum of } \\
\text { Squares }\end{array}$} & Df & Mean Square & F & Sig. \\
\hline Regression & 168.166 & 3 & 56.055 & 14.963 & $.000^{\mathrm{b}}$ \\
1 & 172.334 & 46 & 3.746 & & \\
Residual & 340.500 & 49 & & & \\
\hline
\end{tabular}

a. Dependent Variable: y

b. Predictors: (Constant), x3, x2, x1

Sumber: Pengolahan Data, 2017

Berdasarkan tabel diatas diketahui bahwa variabel lingkungan wajib pajak, kontrol keperilakuan yang dipersepsikan dan kewajiban moral berpengaruh terhadap variabel kepatuhan wajib pajak yaitu dengan nilai sig 0.00 lebih kecil dari 0.05.

\subsubsection{Hasil Uji Parsial (Uji t)}

Uji parsial (uji t), yang dilakukan untuk mengetahui hubungan varibel independen secara individual (parsial) terhadap variabel dependen. 
Tabel 4.7 Hasil Uji Parsial (Uji t)

Coefficients $^{\mathrm{a}}$

\begin{tabular}{|c|c|c|c|c|c|c|}
\hline & \multirow[t]{2}{*}{ Model } & \multicolumn{2}{|c|}{$\begin{array}{c}\text { Unstandardized } \\
\text { Coefficients }\end{array}$} & \multirow{2}{*}{\begin{tabular}{|c|}
$\begin{array}{c}\text { Standardized } \\
\text { Coefficients }\end{array}$ \\
Beta
\end{tabular}} & \multirow[t]{2}{*}{$\mathrm{t}$} & \multirow[t]{2}{*}{ Sig. } \\
\hline & & B & Std. Error & & & \\
\hline & (Constant) & 9.227 & 1.940 & & 4.755 & .000 \\
\hline 1 & $\mathrm{x} 1$ & .360 & .155 & .369 & 2.324 & .025 \\
\hline & $\mathrm{x} 2$ & -.100 & .162 & -.096 & -.616 & .541 \\
\hline & $\mathrm{x} 3$ & .494 & .163 & .469 & 3.022 & .004 \\
\hline
\end{tabular}

Sumber: Pengolahan Data, 2017

Berdasarkan tabel diatas dapat dilihat bahwa lingkungan wajib pajak berpengaruh terhadap kepatuhan wajib pajak, dengan nilai sig 0.25 lebih kecil dari 0.05. Kewajiban Moral berpengaruh terhadap kepatuhan wajib pajak dengan nilai sig 0.004 lebih kecil dari 0.05. Sedangkan Kontrol keperilakuan yang dipersepsikan tidak bepengaruh terhadap kepatuhan wajib pajak dengan nilai sig 0.541 lebih besar dari 0.05 .

\subsubsection{Koefisien Determinasi}

Uji Koefisien Determinasi yang dilakukan untuk mengetahui persentase sumbangan pengaruh variabel independen secara serentak terhadap variabel dependen.

Tabel 4.8 Hasil Uji Koefisien Determinasi Model Summary ${ }^{b}$

\begin{tabular}{|r|r|rr|}
\hline R & R Square & \multicolumn{2}{|c|}{ Adjusted R Square } \\
\hline $.703^{\mathrm{a}}$ & .494 & & .461 \\
\hline
\end{tabular}

a. Predictors: (Constant), $\mathrm{x} 3, \mathrm{x} 2, \mathrm{x} 1$

b. Dependent Variable: y

Sumber: Pengolahan Data, 2017

Berdasarkan tabel 4.8 besarnya R Square (koefisien determinasi yang telah disesuaikan) adalah $49.4 \%$, nilai ini menunjukkan bahwa $49.4 \%$ variasi kepatuhan wajib pajak kelurahan Paal Dua Manado dapat dijelaskan oleh ketiga variabel independen yaitu lingkungan wajib pajak ( $\left.\mathrm{X}_{1}\right)$, kontrol keperilakuan yang dipersepsikan $\left(\mathrm{X}_{2}\right)$, dan kewajiban moral $\left(\mathrm{X}_{3}\right)$, sedangkan sisanya $50.6 \%$ dijelaskan oleh variabel lain yang tidak diteliti dalam penelitian ini.

\subsection{Pembahasan Hasil Penelitian}

\subsubsection{Pengaruh Lingkungan Wajib Pajak terhadap Kepatuhan Wajib Pajak}

Hasil pengujian hipotesis pertama menunjukkan bahwa pada variabel lingkungan waijb pajak, $0.025<0.05$ sehingga lingkungan wajib pajak berpengaruh terhadap kepatuhan wajib pajak orang pribadi di Kelurahan Paal Dua Manado. Ini disebabkan karena masyarakat disekitar lingkungan tersebut melaksanakan kewajiban perpajakanya dengan baik dan benar. Salah satu penyebab masyarakat di Kelurahan Paal Dua Manado melaksanakan kewajiban perpajakanya dengan baik adalah lingkunganya yang kondusif, artinya orang-orang yang ada disekitarnya sudah memberikan pengaruh yang baik bagi mereka dalam mematuhi kewajibanya sebagai wajib pajak seperti memberikan dorogan agar patuh dalam melaporkan pajaknya, memberikan contoh yang baik dengan patuh membayar pajak yang membuat masyarakat pun melakukan perbuatan yang sama. Hasil penelitian ini menunjukkan bahwa semakin baik lingkungan wajib pajak, maka kepatuhan wajib pajak akan semakin baik dan tepat.

Hasil penelitian ini sejalan dengan penelitian yang dilakukan oleh Jotopurnomo dan Mangoting (2013), yang meneliti tentang pengaruh kesadaran wajib pajak, kualitas pelayanan 
fiskus, sanksi perpajakan, lingkungan wajib pajak berada terhadap kepatuhan wajib pajak orang pribadi di Surabaya disimpulkan bahwa lingkungan wajib pajak berpengaruh signifikan terhadap kepatuhan wajib pajak orang pribadi di Surabaya karena apabila masyarakat ditempat lingkungan wajib pajak berada patuh maka wajib pajak pun ikut patuh.

\subsubsection{Pengaruh Kontrol Keperilakuan yang dipersepsikan terhadap Kepatuhan Wajib Pajak}

Hasil pengujian hipotesis kedua menunjukkan bahwa pada variabel kontrol keperilakuan yang dipersepsikan, $0.541>0.05$ sehingga kontrol keperilakuan yang dipersepsikan tidak berpengaruh terhadap kepatuhan wajib pajak orang pribadi di Kelurahan Paal Dua Manado. Dengan adanya kontrol keperilakuan yang dipersepsikan tidak menjamin akan adanya kepatuhan wajib pajak karena, wajib pajak merasa kontrol yang menjadi penghambat mereka melakukan ketidakpatuhan pajak seperti adanya kemungkinan dikenakan sanksi, kemungkinan pelaporan pihak ketiga, dan kemungkinan diperiksa oleh petugas pajak tidak mempengaruhi wajib pajak dalam menampilkan perilaku patuh terhadap pajak. Wajib pajak khususnya yang berada di Kelurahan Paal dua merasa tidak takut ataupun merasa terancam dengan adanya kontrol keprilakuan yang dipersepsikan karena wajib pajak yang berada dikelurahan Paal dua merasa bahwa mereka sudah melakukan kewajibanya sebagai wajib pajak dengan benar dan apa adanya.

Sehingga hasil penelitian ini tidak sejalan dengan penelitian Hardiningsih (2014), yang menyatakan bahwa kontrol keperilakuan yang dipersepsikan berpengaruh positif terhadap kepatuhan wajib pajak, dimana semakin baik persepsi kontrol perilaku wajib pajak, maka akan meningkatkan kepatuhan wajib pajak. Namun, hal ini ternyata tidak sesuai dengan bukti yang diperoleh dalam penelitian ini.

Adapun hasil penelitian ini sejalan dengan penelitian Adibuddin (2015), yang menyatakan bahwa kontrol keperilakuan yang dipersepsikan tidak berpengaruh secara langsung pada kepatuhan pajak. Jadi, adanya persepsi wajib pajak terhadap adanya kontrol yang baik terhadap sistem pengendalian perpajakan yang diterapkan di Indonesia, tidak berpengaruh langsung dengan semakin meningkatnya tingkat kepatuhan wajib pajak.

\subsubsection{Pengaruh Kewajiban Moral terhadap Kepatuhan Wajib Pajak}

Hasil pengujian hipotesis ketiga menunjukkan bahwa pada variabel kewajiban moral, $0.004<0.05$ sehingga kewajiban moral berpengaruh terhadap kepatuhan wajib pajak orang pribadi di Kelurahan Paal Dua Manado. Hasil penelitian ini menunjukkan bahwa semakin baik kewajiban moral yang dimiliki oleh wajib pajak maka kepatuhan wajib pajaknya pun akan semakin baik. Karena setiap wajib pajak yang memiliki moral yang baik dalam dirinya dengan cara pandang positif terhadap pajak dan menganggap pajak itu sebagai suatu kewajiban maka hal itu juga akan membantu wajib pajak dalam memenuhi kewajiban perpajakanya.

Hasil penelitian ini sejalan dengan penelitian yang dilakukan Artha dan Setiawan (2016), yang menunjukkan bahwa kewajiban moral berpengaruh positif terhadap kepatuhan wajib pajak orang pribadi. Artinya, semakin tinggi kewajiban moral, maka kepatuhan wajib pajak akan semakin baik. Etika, prinsip hidup, perasaan bersalah merupakan kaitan dari pemenuhan kewajiban. Wajib pajak merasa memiliki perasaan bersalah apabila tidak memenuhi kewajiban terhadap perpajakanya. Dan hal ini tentu akan membuat wajib pajak selalu patuh dalam pemenuhan perpajakanya.

\section{KESIMPULAN DAN SARAN \\ 5.2 Kesimpulan}

1. Lingkungan Wajib Pajak $\left(\mathrm{X}_{1}\right)$ berpengaruh terhadap kepatuhan wajib pajak $(\mathrm{Y})$ orang pribadi di Kelurahan Paal Dua Manado, sehingga hipotesis pertama diterima. Hal ini 
menunjukkan bahwa semakin baik lingkungan wajib pajak maka kepatuhan wajib pajak juga akan semakin baik.

2. Kontrol Keperilakuan yang dipersepsikan $\left(\mathrm{X}_{2}\right)$ tidak berpengaruh terhadap kepatuhan wajib pajak (Y) orang pribadi di Kelurahan Paal Dua Manado, sehingga hipotesis kedua ditolak. Hasil penelitian ini menunjukkan bahwa wajib pajak sudah melakukan kewajibanya dengan baik sehingga tidak merasa takut atau terancam bila terjadi kontrol keperilakuan yang dipersepsikan.

3. Kewajiban moral $\left(\mathrm{X}_{3}\right)$ berpengaruh terhadap kepatuhan wajib pajak (Y) orang pribadi di Kelurahan Paal Dua Manado, sehingga hipotesis ketiga diterima. Hal ini menunjukkan bahwa semakin baik kewajiban moral yang dimiliki oleh wajib pajak maka kepatuhan wajib pajak juga akan semakin baik.

\subsection{Saran}

Berdasarkan hasil penelitian dan kesimpulan, maka saran-saran yang dapat diberikan berkaitan judul adalah sebagai berikut :

1. Untuk penelitian berikutnya dalam wilayah pembagian kuesioner lebih diperluas dengan menambah jumlah responden yang sesuai.

2. Dapat menambah variabel bebas seperti kualitas pelayanan, sanksi perpajakan, kemanfaatan NPWP, dan sikap rasional yang belum bisa digambarkan dalam penelitian ini.

\section{DAFTAR PUSTAKA}

Aryobimo. 2012. Pengaruh Persepsi Wajib Pajak Tentang Kualitas Pelayanan Fiskus Terhadap Kepatuhan Wajib Pajak Dengan Kondisi Keuangan Wajib Pajak Dan Preferensi Risiko Sebagai Variabel Moderating (Studi Empiris Terhadap Wajib Pajak Orang Pribadi di Kota Semarang). Skripsi Undip. Fakultas Ekomomika Dan Bisnis Universitas Diponegoro Semarang.

Adibuddin, Ahmad Farras. 2015. Analisis Faktor-Faktor yang mempengaruhi Tax Compliance Penyetoran SPT Masa di KPP Pratama Boyolali. Skripsi. Universitas Muhammadiyah Surakarta.

Alfiah, Irma. 2014. Kesadaran Perpajakan, Sanksi Pajak, Sikap Fiskus, Lingkungan Pajak, Pengetahuan Peraturan Perpajakan, Persepsi Efektifitas Sistem Perpajakan, Kemauan Membayar Pajak Terhadap Kepatuhan Wajib Pajak Orang Pribadi di DPPKAD Purwodadi. Skripsi. Universitas Muria Kudus.

Artha, Ketut Gede Widi dan Setiawan Putu Ery. 2016. Pengaruh Kewajiban Moral, Kualitas Pelayanan, Sanksi Perpajakan Pada Kepatuhan Wajib Pajak di KPP Badung Utara. E-Jurnal Akuntansi. Vol. 17, No. 1, November 2016. Univeritas Udayana.

Ayu, Dyah. 2011. Persepsi Efektifitas Pemeriksaan Pajak Terhadap Kecenderungan Perlawanan Pajak. Seri Kajian Ilmiah. Vol. 14, No. 1, Januari 2011.

Agustiantono, Dwi, 2012. Analisis faktor-faktor yang mempengaruhi kepatuhan wajib pajak orang pribadi di kabupaten Pati. Skripsi. Universitas Diponegoro Semarang.

Akhand, Zakir dan Hubbard Michael. 2016. Coercion, Persuasion, and Tax Compliance: The Case of Large Corporate Taxpayers. Canadian Tax Journal / Revue Fiscale Canadianne (2016) 64:1, 31-36. University of Exeter, UK.

Benk, Serkan, Tamer Budak, Buhadir Yuzbaz dan Raihana Mohdali. 2015. The Impact of Religiosity on Tax Compliance among Turkish Self-Employed Taxpayers Religions. Inonu University. Turkey.

Dewi, Anak Agung Sri Intan Komala dan Setiawan Putu Ery. 2016. Pengaruh Kesadaran, Kualitas Pelayanan, Kewajiban Moral dan Persepsi Sanksi Perpajakan Pada 
Kepatuhan Wajib Pajak Reklame. E-Jurnal Akuntansi, Vol. 17 No. 1, Oktober 2016. Universitas Udayana.

Gangl, Kathrina, Eva Hoffman dan Erich Kirchler. 2015. Tax Authorities `interaction with taxpayers: A conception of compliance on social dilemmas by power and trust. 37: 13-23, 2015 Feb. University of cologne. Austrian.

Ghozali, Imam. 2013. Aplikasi Analisis Multivariat dengan Program IBM SPSS 21. Edisi 7. Semarang: Universitas Diponegoro.

Hardiningsih, Pancawati. 2014. Determinan Kepatuhan Wajib Pajak Badan. Vol. 3 No. 1, November 2014. Universitas Stikubank Semarang.

Heri, 2015. Akuntansi Perpajakan. Jakarta: PT. Gramedia. Wydia Sarana Indonesia.

Hidayat, W. dan A. A. Nugroho, 2010. Studi Empiris Theory of Planned Behavior dan Pengaruh Kewajiban Moral pada Perilaku Ketidakpatuhan Pajak Wajib Pajak Orang Pribadi. Badan Penerbit Jurnal Akuntansi Dan Keuangan. Vol. 12 No. 2, Surabaya.

I'anatut, Thoifah. 2015. Statistika Pendidikan dan Metode Penelitian Kuantitatif. Madani, Malang.

Jotopurnomo, Cindy dan Yenni Mangoting. 2013. Pengaruh Kesadaran Wajib Pajak, Kualitas Pelayanan Fiskus, Sanksi Perpajakan, Lingkungan Wajib Pajak Berada Terhadap Kepatuhan Wajib Pajak Orang Pribadi di Surabaya. Tax \& Accounting Review. Vol. 1 No. 1, 2013. Universitas Kristen Petra.

Kristina, 2015. Pengaruh Kesadaran Wajib Pajak, Kualitas Pelayanan, Ketegasan Sanksi dan Kewajiban Moral Terhadap Kepatuhan Wajib Pajak Dalam Membayar Pajak Reklame (Studi Kasus Dinas Pendapatan Daerah Kota Pekanbaru). Jom FEKON Vol. 2 No. 2 Oktober 2015. Universitas Riau.

Mardiasmo, 2016. Perpajakan. Edisi Terbaru 2016, CV. Andi Offset, Yogyakarta.

Meutia, Mukhtaruddin. 2013. Taxpayer Compliance inTax Filling at Palembang City. Prosiding Simposium Nasional Perpajakan 4.

Mwangi, Patrick C. Ndegwa. 2014. Factors influencing tax compliance among small and medium enterprises in nairobi's industrial area, Kenya. University of Nairobl. Kenya.

Nalendro, Tantra Ikhlas. 2014. Faktor-faktor yang mempengaruhi Kepatuhan Membayar Pajak Wajib Pajak Orang Pribadi yang Berwirausaha dengan Lingkungan Sebagai Variabel Moderasi. Skripsi. Universitas Diponegoro.

Palil, Mohd Rizal, Mohamad Abdul Hamid, dan Mohd Hizam Hanafiah. 2013. Taxpayer Compliance Behavior : Economic Factor Approach. Jurnal Pengurusan 38 (2013) 7588. Universiti Kebangsaan Malaysia.

Pangestu, F. dan Oman Rusmana. 2012. Analisis Faktor-Faktor Yang Berpengaruh Terhadap Tax Compliance Penyetoran SPT Masa. Penerbit Fakultas Ekonomi Universitas Jenderal Soedirman. Purwokerto.

Pemerintah RI, Undang-undang RI No. 28 Tahun 2007 Pasal 1 Angka 2 tentang Ketentuan Umum dan Tata Cara Perpajakan.

Pohan, Chairil Anwar. 2013. Manajemen Perpajakan: Strategi Perencanaan Pajak dan Bisnis. Gramedia Pustaka Utama

Putri, Layli Yobapritika. 2014. Pengaruh Sikap, Norma Subjektif, dan Kontrol Keperilakuan yang dipersepsikan Terhadap Kepatuhan Wajib Pajak Orang Pribadi di Kota Yogyakarta. Skripsi. Universitas Negeri Yogyakarta.

Putri, Amanda R. Siswanto. 2013. Faktor-faktor yang mempengaruhi kepatuhan wajib pajak dalam membayar pajak kendaraan motor di Denpasar. Skripsi. Universitas Udayana, Bali.

Primasari, Nora Hilmia. 2016. Faktor-faktor yang mempengaruhi kepatuhan wajib pajak orang pribadi yang melakukan pekerjaan bebas. Jurnal Akuntansi dan Keuangan, Vol. 5 No. 2 Oktober 2016. Universitas Budi Luhur Jakarta. 
Rahayu, Puji. 2015. Pengaruh Kualitas Pelayanan, Kewajiban Moral dan Sanksi Perpajakan Terhadap Kepatuhan Wajib Pajak Hotel Dalam Membayar Pajak Hotel di kota Pekanbaru. Jom FEKON Vol. 2 No. 2, Oktober 2015. Universitas Riau.

Rahayu, Siti Kurnia. 2013. Perpajakan Indonesia Konsep dan Aspek Formal. Yogyakarta: Graha Ilmu.

Renza, Ayu Mila. 2015. Pengaruh Kualitas Pelayanan, Kewajiban Moral, dan Sanksi Perpajakan Terhadap Kepatuhan Wajib Pajak Dalam Membayar Pajak Hotel di Kota Surakarta. Skripsi. Universitas Muhammadiyah Surakarta.

Santi, Anisa Nirmala. 2012. Analisis Pengaruh Kesadaran Perpajakan, Sikap Rasional, Lingkungan, Sanksi Denda dan Sikap Fiskus Terhadap Kepatuhan Wajib Pajak (Studi Empiris Pada WPOP di Wilayah KPP Pratama Semarang). Diponegoro Journal Of Accounting.

Sodikin, Slamet Sugiri dan Riyono Bogat Agus. 2014. Akuntansi Pengantar 1. Edisi kesembilan. Penerbit UPP STIM YKPN.

Sugiyono. 2014. Metode Penelitian Bisnis (Pendekatan Kuantitatif, Kualitatif dan R\&D). Bandung: Alfabeta.

Sugiyono. 2016. Metode Penelitian (Kuantitatif, Kualitatif, dan R\&D). Bandung: Alfabeta.

Sunyoto D. 2013. Metodologi Penelitian Akuntansi. Cetakan Satu. Bandung: Refika Aditama. Sujarweni. 2015. Akuntansi Sektor Publik. Penerbit Pustaka Baru Press. Yogyakarta.

Wanarta, Feby Eileen dan Yenny Mangoting. 2014. Pengaruh Sikap Ketidakpatuhan Pajak, Norma Subjektif, dan Kontrol Perilaku yang dipersepsikan Terhadap Niat Wajib Pajak Orang Pribadi Untuk Melakukan Penggelapan Pajak. Tax \& Accounting Review Vol. 4 No. 1, 2014. Universitas Kristen Petra. Surabaya.

Warren, Carl S, Reeve, James M, dan Duchac Jonathan E. 2014. Pengantar AkuntansiAdaptasi Indonesia. Edisi 25. Salemba Empat. Jakarta

Waluyo, 2013. Perpajakan Indonesia. Edisi Kesebelas Buku I. Salemba Empat. Jakarta

Widyastuti, Ella. 2015. Pengaruh Tingkat Pemahaman Wajib Pajak, Kualitas Pelayanan Fiskus, Sanksi Perpajakan, dan Lingkungan Wajib Pajak Terhadap Tingkat Kepatuhan Wajib Pajak Orang Pribadi di KPP Pratama Surakarta. Skripsi. Universitas Muhammadiya Surakarta.

Winarsih, Endang Sri. 2015. Faktor-Faktor Yang Mempengaruhi Niat Ketidakpatuhan Dalam Membayar Pajak. Skripsi. Universitas Sebelas Maret Surakarta.

Yuliyanti, Ika. 2016. Pengaruh Pemahan Wajib Pajak, Kualitas Pelayanan Perpajakan, Sanksi Perpajakan dan Kondisi Lingkungan Terhadap Tingkat Kepatuhan Wajib Pajak Orang Pribadi di KPP Pratama Surakarta. Skripsi. Universitas Muhammadiyah Surakarta. 